\title{
ZNAČILNOSTI, VZROKI IN POSLEDICE DEINDUSTRIALIZACIJE V MARIBORU
}

\author{
Andreja Slavec*
}

Izvleček

UDK 911·3:330.341.424 (497.12 Maribor)

$V$ članku so prikazane osnovne značilnosti deindustrializacije $v$ industrijsko visoko razvitih državah in poskus ovrednotenja tega proces $v$ Mariboru konec 80-tih let.

Ključne besede: gospodarska kriza, negativna in pozitivna deindustrializacija, Maribor, brezposelnost

\section{CHARACTERISTICS, CAUSES AND RESULTS OF DEINDUSTRIALIZATION IN MARIBOR}

Abstract

UDC 911·3:330.341.424 (497.12 Maribor)

The article deals with the basic characteristcs of the process of de-industrialization in highly developed industrial countries. It also tries to evaluate this process in Maribor, which dates into the end of 80 's.

Key words: economic depression, positive and negative de-industrialization, Maribor, unemployement

\section{OSNOVNA SPOZNANJA O ZAČETKIH, RAZVOJU, GLAVNIH ZNAČILNOSTIH IN VZROKIH DEINDUSTRIALIZACIJE V INDUSTRIJSKO VISOKO RAZVITIH KAPITALISTIČNIH DRŽAVAH}

Zapiranje tovarn in stečaji podjetij so pogosto del veliko širšega procesa - deindustrializacije, ki se pogosto ocenjuje za znamenje šibkosti gospodarstva. Vendar pa nekateri avtorji menijo, da je takšna sodba neutemeljena. S. Fothergill in N. Guy v svoji knjigi "Retreat from the Regions" (1990) pravita, da so družbeni proizvod, delovna sila in njuna struktura odvisni od stopnje družbeno-ekonomskega razvoja, ki ga je neka družba dosegla. Sprva so se kmetje preobrazili v industrijske delavce, kasneje pa se je zmanjšalo število teh in se povečalo število zaposlenih v terciarnem in kvartarnem sektorju. Posebno preslojevanje industrijskih delavcev $\mathrm{v}$ uslužbence storitvenih dejavnosti je bilo odvisno od razlik $v$ delovni produktivnosti med obema

\footnotetext{
*Mag., asistent, Oddelek za geografijo, Filozofska fakulteta Univerze v Ljubljani, Aškerčeva 2, 61000 Ljubljana, Slovenija.
} 
sektorjema. Za povečanje enote družbenega proizvoda v terciarnem in kvartarnem sektorju je bilo potrebno zaposliti več novih delavcev kot $\mathbf{v}$ industriji, kjer je delovno silo nadomestila močno izpopolnjena strojna oprema. Glede na navedeno, lahko v storitvenih dejavnostih in $v$ industriji opazimo rast družbenega proizvoda, medtem ko število zaposlenih $\mathrm{v}$ terciarnem in kvartarnem sektorju raste, $\mathrm{v}$ industriji pa pada $\mathrm{v}$ absolutnem in relativnem pogledu. Fothergill in Guy menita, da je deindustrializacija samo normalna stopnja družbeno-ekonomskega razvoja neke družbe.

Rowthorn in Wells (1987) pravita, da obstajata dva tipa deindustrializacije. Pozitivna deindustrializacija nastopi, ko dinamična in uspešna industrija odpušča delavce zaradi dviga produktivnosti. $V$ takšnem primeru je za celotno gospodarstvo značilna nizka brezposelnost in rast družbenega proizvoda. Storitvene dejavnosti pa zaposlujejo presežke industrijske delovne sile.

Negativna deindustrializacija nastopi, ko industrijski družbeni proizvod raste počasi ali celo upada in s tem negativno vpliva na rast celotnega gospodarstva. Odpuščeni delavci ne najdejo zaposlitve $v$ storitvenih dejavnostih, tako da število brezposelnih hitro raste.

Deindustrializacija sama po sebi zato ne more biti indikator uspešnosti oziroma neuspešnosti nekega gospodarstva. Njen pozitivni ali negativni vpliv je treba presoditi s kazalci kot sta na primer stopnja brezposelnosti in delež industrije $\mathrm{v}$ družbenem proizvodu.

Deindustrializacija je najprej in najbolj intenzivno prizadela velika mesta in stara industrijska središča v visoko industrializiranih državah Zahodne Evrope, Združenih državah Amerike in na Japonskem. Število zaposelnih v industriji se je močno zmanjšalo. Razlogi, ki so pripeljali do tega procesa, so:

1. Decentralizacija industrijske proizvodnje iz mest $v$ suburbanizirana območja in iz centralnih $\mathrm{v}$ robna območja. $Z$ decentralizacijo industrije se je spremenila geografska razporeditev industrijskih podjetij in delovne sile. Industrijska delovna sila v mestih in starih industrijskih območjih je bila namreč veliko bolj organizirana (sindikati) in $s$ tem uspešnejša pri zagotavljanju višjih plač in pravic. $Z$ decentralizacijo industrije pa se je začela reorganizacija kapitala in delovne sile; močno se je spremenilo tudi tržišče, ki je postalo območje vedno večje konkurence.

2. Industrijska struktura $v$ mestih, ki se močno razlikuje od splošne industrijske strukture, je lahko eden izmed razlogov za nazadovanje. Če mestno industrijo sestavljajo industrijske panoge, $\mathrm{ki}$ so doživele največje nazadovanje $\mathrm{v}$ državnem pogledu, so lahko posledice katastrofalne.

3. $\mathrm{V}$ mestih pogosto prevladujejo stara industrijska podjetja, ki imajo praviloma 
zastarela proizvajalna sredstva in se težje prilagajajo novim ekonomskim razmeram ter počasneje uvajajo vse oblike tehničnih, tehnoloških in organizacijskih inovacij.

4. $Z$ industrializacijo se je spreminjal tudi pomen posameznih razmestitvenih dejavnikov. V začetku tega procesa so imela mesta prednosti pred drugimi območji, saj so običajno ležala na stičišču pomembnih prometnih poti in tovarne $v$ mestih so imele veliko večje možnosti za nemoteno oskrbo s surovinami in energetskimi viri ter hiter odvoz izdelkov na tržišče. Današnja relativno cenena oskrba s surovinami, polizdelki in energijo, razvoj telekomunikacij in izpopolnjena prometna infrastruktura so močno zmanjšali privlačnost mest za industrijo. Zaradi višje kvalificirane in s tem dražje delovne sile, velike konkurence med podjetji in visokih cen mestnega zemljišča, se je industrija začela izogibati mest. Stroški proizvodnje v mestu so začeli naraščati, dobiček pa je bil vedno manjši.

5. Preoblikovanje proizvodnje je odvisno od gospodarskih težav, ki so zajele posamezno industrijsko panogo oziroma podjetje. Do deindustrializacije pride zaradi prestrukturiranja proizvodnje ter uvajanja tehničnih, tehnoloških in organizacijskih inovacij.

Zmanjšano povpraševanje po določenem izdelku povzroča nezadostno izkoriščenosti proizvodnih zmogljivosti in visoke proizvodne stroške. Kljub stabilnemu povpraševanju po izdelkih so podjetja zaradi naraščajoče konkurence prisiljena neprestano paziti na konkurenčnost cen.

V prvem primeru je potrebno znižati proizvodnjo in stroške. Majhne izboljšave se lahko dosežejo $\mathrm{z}$ večjo produktivnostjo zaposlene delovne sile oziroma $\mathrm{z}$ intenzifikacijo proizvodnje ali pa $\mathrm{z}$ odpuščanjem delavcev; $\mathrm{s}$ tem se znižajo stroški delovne sile. V primeru, ko je treba proizvodnjo močno znižati in intenzifikacija dela industrijskih delavcev ni možna, je zaprtje tovarne veliko bolj učinkovita metoda.

V drugem primeru, ko se podjetje bori z močno konkurenco, lahko večjo učinkovitost dosežemo $\mathrm{z}$ investicijami $\mathrm{v}$ inovacije in tehnološke spremembe proizvodnega procesa. $\mathrm{Na}$ ta način se proizvodnja racionalizira. Povečanje proizvodnih kapacitet, ni nujno povezano s povečanjem števila zaposlenih, saj nova tehnologija in avtomatizacija povečujeta delovno storilnost.

Intenzifikacija proizvodnje zmanjša število zaposlenih, racionalizacija pa povzroči odpuščanje velikega števila delavcev ali celo zaprtje tovarne. Racionalizacija, povezana $\mathrm{z}$ uvajanjem nove tehnologije, lahko pripelje do različnih prostorskih učinkov: od odpiranja novih tovarn in nastanka tovarn na novih lokacijah, do upada števila zaposlenih in celo do zaprtja tovarn.

Navedene značilnosti procesa deindustrializacije in vzroke zanj smo povzeli po raziskavah, ki so jih izdelali v industrijsko visoko razvitih državah. Zato so v veliki meri 
odvisne od pogojev kapitalističnega tržno usmerjenega gospodarstva. V do nedavno socialističnih državah se je deindustrializacija začela šele $v$ zadnjih nekaj letih, in sicer iz drugačnih razlogov in ima drugačne značilnosti.

\section{OSNOVNE ZNAČILNOSTI, VZROKI IN POSLEDICE DEINDUSTRIALIZACIJE V MARIBORU}

$\mathrm{V}$ drugi polovici osemdesetih let se je začelo najbolj dramatično obdobje v povojnem gospodarskem razvoju Maribora. Eno izmed najstarejših in do leta 1960 tudi največje industrijsko središče $v$ Sloveniji se je sicer $v$ obdobju po drugi svetovni vojni $v$ primerjavi z ostalimi industrijskimi kraji v Sloveniji razvijalo počasi, gospodarska kriza pa je z vso silovitostjo udarila na dan šele konec osemdesetih let.

Analize so pokazale, da je bilo leta 1991 v mariborski industriji zaposlenih 28.397 delavcev ali samo 724 delavcev več kot leta 1961. Po letu 1987, ko je industrija dosegla največje število zaposlenih: 38.510 delavcev, se je začelo obdobje hitrega nazadovanja števila zaposlenih. V primerjavi z letom 1987 je bilo število delavcev leta 1991 manjše za 10.113 , leta 1993 pa za 13.296 in je znašalo 25.214 delavcev. To pomeni, da je industrijska podjetja v mestu zapustil vsak četrti delavec, saj se je njihovo število zmanjšalo za 26,26 \%. Največji upad je bil opazen leta 1990 in 1991. Po letu 1987 je tudi v slovenski industriji začelo upadati število zaposlenih $v$ industriji, vendar je bil ta upad veliko manjši kot v Mariboru. V štirih letih se je v Sloveniji število zaposlenih zmanjšalo za $15,09 \%$, vendar močneje šele po letu 1991 . V Mariboru pa ni nazadovalo samo število industrijskih delavcev, ampak tudi delež industrije $v$ ustvarjenem družbenem proizvodu. Podatki za občino Maribor kažejo, da se je ta delež znižal od $50,46 \%$ leta 1987 oziroma $55,24 \%$ leta 1988 na samo $43,47 \%$ leta 1990 . Po letu 1987 je torej začel slabeti tudi ekonomski pomen industrije $\mathrm{v}$ okviru mestnega gospodarstva in tudi $\mathrm{v}$ okviru celotne slovenske industrije. Deleži družbenega proizvoda vseh ostalih sektorjev pa so se povečali (Slavec, 1992).

Na osnovi navedenega lahko sklepamo, da imamo v Mariboru opravka s tako imenovano negativno obliko deindustrializacije. Glede uporabe tega termina bi se lahko pojavile številne razprave in nesoglasja. Postavlja se namreč vprašanje razlike med pojmoma deindustrializacija in gospodarska kriza. Tudi v tuji literaturi uporaba enega pojma ne izključuje uporabe drugega. Zelo težko je namreč potegniti mejo med obema (The Dictionary of Human Geography, 1990, str. 97)

Vzrokov za tolikšno krizo mariborske industrije je več in jih ne moremo obravnavati ločeno, ampak v njihovi medsebojni odvisnosti in prepletenosti.

1. Eden izmed osnovnih razlogov je bila prav gotovo decentralizacija industrijske proizvodnje po drugi svetovni vojni kot posledica zavestne industrializacijske politike in politike policentričnega razvoja Slovenije. 
Pred letom 1945 so bili glavni industrijski centri Maribor, Kranj, Celje in Ljubljana, poleg njih pa še zlasti Črni revir, Mežiška in Šaleška dolina ter Gorenjska, preostala območja pa so bila slabo ali povsem neindustrializirana (Vrišer, 1977). Po drugi svetovni vojni se je ta slika močno spremenila. Povojna industrializacija je ustvarila celo vrsto novih industrijskih središč, kot so koprsko, novogoriško, novomeško, murskosoboško, cerkniško, ... ter okrepila nekatera stara: celjsko, velenjsko, škofjeloško. Industrija se je razvila tudi $\mathrm{v}$ nekaterih do tedaj povsem neindustrializiranih območjih (Gornja Radgona, Ljutomer, Tolmin, Trebnje) (Vrišer, 1977, str. 38). Nastopila je prerazporeditev industrije in industrijske delovne sile. Razlike $v$ stopnji industrializacije med posameznimi območji so se začele manjšati. Medtem ko je bil v kapitalističnih državah osnovni razlog za decentralizacijo industrijske proizvodnje zmanjšanje stroškov proizvodnje in $\mathrm{s}$ tem večji dobiček, je $\mathrm{v}$ razmerah socialističnega gospodarstva prevladala politika skladnega regionalnega razvoja; ta je vsem krajem skušala zagotoviti podobne možnosti za ekonomski razvoj. Pri tem pa so le redko upoštevali ekonomičnost graditve industrijskih obratov. Maribor je kot staro industrijsko središče, ki je še leta 1952 ustvarilo $15,38 \%$ industrijskega narodnega dohodka Slovenije, ostal na robu teh procesov. Celo nasprotno, velik del svoje akumulacije je mariborska industrija $\mathrm{v}$ prvih povojnih letih odvajala za razvoj industrije $\mathrm{v}$ preostalih predelih Slovenije.

2. S spremembami $v$ vrednotenju posameznih lokacijskih dejavnikov je mesto izgubilo številne prednosti, ki jih je imelo v preteklosti. Ugodna lega ob Južni železnici in bližina dravskega hidroenergetskega sistema, ki je mestu zagotavljal nemoteno oskrbo z električno energijo, sta bila najpomembnejša lokacijska dejavnika pred drugo svetovno vojno. $Z$ izboljšanjem prometne infrastrukture $v$ Sloveniji in razvojem elektroenergetskega omrežja pa sta ta dva faktorja izgubila na pomenu. Industrija se lahko razvije pravzaprav povsod (Slavec, 1992).

3. Pomemben faktor, ki je vplival na deindustrializacijo, je bila prav gotovo tudi starost industrijskih podjetij v Mariboru. Kar $72,72 \%$ vseh tovarn je bilo ustanovljenih pred letom 1951. Številne tovarne so imele zastarela proizvajalna sredstva. Investicije $\mathrm{v}$ industrijo so bile skromne; relativni delež investicij $\mathrm{v}$ mariborsko industrijo od vseh naložb v industrijo Slovenije se je po letu 1971 (podatkov za prejšnje obdobje na žalost ni) močno zmanjšal. Dobljena sredstva niso omogočala nujno potrebne posodobitve proizvodnje $v$ tehničnem, tehnološkem in organizacijskem smislu. Poleg tega je za starejša podjetja značilno, da veliko težje uvajajo izboljšave in inovacije (Slavec, 1992).

4. Zelo pomemben razlog za nazadovanje gospodarskega pomena mariborske industrije v mestu in celotni Sloveniji je bila panožna struktura industrije. Pojavljale so se velike razlike med panožno strukturo mariborske in slovenske industrije, in sicer tako po številu zaposlenih kot tudi po ustvarjenem družbenem proizvodu. Vse panoge 
mariborske industrije, ki so bile temelj povojne industrializacije, so se razvijale veliko počasneje kot v Sloveniji. Leta 1989 je bilo v industrijskih panogah, ki so v obdobju 1961-89 izkazovale počasnejšo rast, zaposlenih $85,9 \%$ vseh industrijskih delavcev v Mariboru. Zaradi razlik $\mathbf{v}$ industrijski strukturi so bili tudi pogoji gospodarjenja različni. Mariborska industrija (predvsem predelava kovin, proizvodnja električnih strojev in aparatov, strojna industrija) je bila usmerjena v proizvodnjo investicijske opreme. Te panoge pa so bile ob minimalnih investicijah $v$ najtežjem položaju. $Z$ industrijsko strukturo, ki se je v Mariboru sicer razvijala v smeri diverzifikacije, lahko delno razložimo in pojasnimo vzroke za nazadovanje te dejavnosti (Slavec, 1992).

5. Medtem ko je $v$ visoko industrializiranih državah Zahodne Evrope, $v$ Združenih državah Amerike, na Japonskem in drugod pomemben razlog za zmanjšanje števila zaposlenih $v$ industriji preoblikovanje industrijske proizvodnje (racionalizacija, intenzifikacija, tehnološke spremembe), je bil v Sloveniji ta proces še skoraj neopazen in prisoten le $\mathbf{v}$ redkih podjetjih. $\mathrm{V}$ večini primerov je bilo preveliko število delavcev $\mathrm{v}$ podjetjih posledica neracionalnega in neekonomskega zaposlovanja $\mathrm{v}$ preteklosti. Pojavila se je t.i. skrita brezposelnost, saj delavci v številnih podjetjih niso imeli dela; posledica tega je bila nizka stopnja produktivnosti. Zaradi zakonskega varovanja delavcev, jih iz podjetij tudi ni bilo mogoče odpustiti. Nova zakonodaja s tega področja je omogočila odpuščanje delavcev, in to se je po letu 1989 pokazalo z vso silovitostjo. Kljub temu, da so se v podjetjih te problematike lotili skrajno previdno in načrtno, je racionalizacija proizvodnje terjala močno zmanjšanje števila zaposlenih.

6. Eden izmed pomembnih vzrokov, ki je še poglobil hudo gospodarsko krizo in je opazen $v$ celotnem slovenskem gospodarstvu, je bil prehod na tržno gospodarstvo, kakršnega poznajo $\mathrm{v}$ kapitalistinih državah. $V$ naših podjetjih se $\mathrm{v}$ preteklosti ni nacrtno razvijala podjetniška miselnost. Postopen prehod na tržno gospodarstvo se je začel že $\mathrm{v}$ okviru nekdanje Jugoslavije $\mathrm{z}$ uvedbo protiinflacijskega programa decembra 1989. Le-ta je temeljil na konceptu odpiranja in ustvarjanja normalnih tržnih razmer. Vendar pa se je slovenska vlada šele z osamosvojitvijo Slovenije junija 1991 pospešeno lotila priprave reform, ki naj bi slovenskemu gospodarstvu omogočile normalen razvoj na odprtem tržišču.

Takšne neurejene razmere gospodarjenja - v letih 1990 in 1991 so se jim pridružili še razpad enotnega jugoslovanskega tržišča, zalivska vojna in vojna v Sloveniji - so prav gotovo zelo negativno vplivale na rast industrijske proizvodnje in "življenje" podjetij na sploh. Poleg splošnih razlogov, ki so negativno vplivali na razvoj celotne slovenske industrije, smo navedli tudi razloge, ki so po našem mnenju specifični za mariborsko gospodarstvo. Neugodna kombinacija naštetih vzrokov je usodno vplivala na razvoj industrije $\mathrm{v}$ mestu in povzročila hudo gospodarsko krizo. Zaradi velike koncentracije števila industrijskih delavcev in prebivalcev, ki so življenjsko odvisni od dela $v$ industriji, je morda kriza $v$ Mariboru veliko bolj izrazita in očitna kot $v$ drugih industrijskih središčih v Sloveniji. 
Posledice deindustrializacije so številne:

1. Močno je upadlo število zaposlenih v industriji. V obdobju od leta 1987 do maja 1991 se je zmanjšsalo število delavcev $v$ vseh vodilnih industrijskih panogah $v$ mestu. Največji upad je bil viden v proizvodnji prometnih sredstev, saj je tovarne zapustilo kar 4666 delavcev. V proizvodnji preje in tkanin se je število zmanjšalo za 970, v predelavi kovin za 898 , v proizvodnji električnih strojev in aparatov za 817 in proizvodnji obutve in galanterije za 656 delavcev. Število zaposlenih se je zmanjšalo v vseh industrijskih panogah, razen v proizvodnji krmil. Problema odvečne delovne sile so se $v$ podjetjih lotili na različne načine. Potem ko so v podjetju ugotovili, da delavec zaradi tehnoloških, strukturnih (neustrezna kvalifikacija), organizacijskih in ekonomskih razlogov postane nepotreben, so ga opredelili kot presežnega delavca. Če takšen status traja več kot šest mesecev, ga prekvalificirajo $v$ trajno presežnega delavca. Zakon o zaposlovanju in zavarovanju za primer brezposelnosti predvideva, da delodajalec sprejme "program razreševanja presežkov delavcev", $v$ katerem določi ukrepe za preprečitev ali kar največjo omejitev prenehanja delovnega razmerja delavcev, seznam nepotrebnih delavcev ter ukrepe in kriterije za izbiro ukrepov za omilitev škodljivih posledic prenehanja delovnega razmerja (Zakon o delovnih razmerjih, 1991). Problematika trajno presežnih delavcev se lahko rešuje na različne načine: s ponudbo zaposlitve $\mathrm{v}$ drugem podjetju, $\mathrm{z}$ zagotovitvijo denarne pomoči, zagotovitvijo pomoči za začetek samostojne dejavnosti, $\mathrm{z}$ dokupom zavarovalne dobe ...

Ker Zavod za zaposlovanje Maribor ne registrira in analizira podatkov o brezposelnih delavcih, ki so bili odpuščeni iz mestnih industrijskih podjetij, smo skušali s pomočjo ankete ugotoviti, koliko odpuščenih delavcev je "pristalo" na mariborskem zavodu za zaposlovanje. Na osnovi podatkov za 32 industrijskih podjetij v mestu (od 55-tih) smo ugotovili, da se je leta 1988 samo $0,14 \%$ odpuščenih delavcev prijavilo na Zavodu za zaposlovanje. Do leta 1989 se je ta delež nekoliko povečal na $1,52 \%$, leta 1990 pa je znova znašal samo $0,31 \%$. Leta 1991 je bil ta delež s $4,89 \%$ največji in se v zadnjih treh letih še povečuje.

V letu 1990 se je $11,22 \%$ delavcev upokojilo z dokupom zavarovalne dobe, leta 1991 pa je ta delež znašal že $19,14 \%$.

Posebno kategorijo so predstavljali tisti odpuščeni delavci, ki so prejeli denarno pomoč za začetek samostojne dejavnosti. Teh je bilo leta 1990 15,64 \%, leta 1991 pa kar $21,38 \%$. Vendar pa je treba povedati, da so ti podatki le približni, saj niso zajeli vseh industrijskih podjetij v mestu. Če bi upoštevali še preostala podjetja, predvsem tista, v katerih je bil stečajni postopek že zaključen, oziroma je še tekel, bi bila slika verjetno nekoliko drugačna. Povečala bi se predvsem kategorija delavcev, ki so prijavljeni na Zavodu za zaposlovanje. S to analizo smo želeli opozoriti predvsem na dejstvo, da zmanjšanje števila industrijskih delavcev ne pomeni avtomatičnega povečanja števila brezposelnih oziroma iskalcev nove zaposlitve (Slavec, 1992). 
2. Kljub temu pa je brezposelnost $v$ Mariboru močno narasla. Po podatkih Zavoda za zaposlovanje se je število brezposelnih v občini Maribor z 2166 delavcev leta 1987 povečalo na 9184 delavcev leta 1991 oziroma 9981 marca 1992. Predstavljali so $10,54 \%$ vseh brezposelnih v Sloveniji. (Mesečna informacija Republiškega zavoda za zaposlovanje, Območna enota Maribor, marec 1992) Trajno presežnih delavcev in "stečajnikov" iz industrije, gradbeništva, finančno-tehničnih in poslovnih dejavnosti je bilo marca 19921419 ali $14,21 \%$ vseh brezposelnih v občini Maribor. Med brezposelnimi je bilo marca $1992 \mathrm{kar} 45,26 \%$ mladih, starih do 26 let in $21,04 \%$ iskalcev prve zaposlitve.

Kot kažejo podatki, velika brezposelnost $v$ mestu ni bila $v$ tolikšni meri neposredna posledica deindustrializacije, ampak $v$ večji meri posreden učinek. Odpuščeni industrijski delavci so predstavljali le manjši del brezposelne populacije. Pač pa se je po letu 1987 zaustavilo zaposlovanje novih delavcev $v$ industriji. Ta najpomembnejša gospodarska dejavnost $v$ mestu, ki je leta 1981 zaposlovala kar $38,5 \%$ vseh aktivnih prebivalcev $v$ mestu in veliko okoliških prebivalcev, je povsem zaprla svoja vrata za novo delovno silo. $\mathrm{V}$ industriji praktično niso zaposlovali novih delavcev, saj so podjetja s prekvalifikacijo svojih delavcev in notranjo reorganizacijo zaposlenih reševala probleme delavcev $v$ podjetju.

Število novih delovnih mest $v$ terciarnih in kvartarnih dejavnostih je raslo sorazmerno počasi. V nekaterih dejavnostih so se celo pojavili presežni delavci. Zmanjšanje števila delovnih mest $v$ industriji, počasen razvoj terciarnega in kvartarnega sektorja ter vedno več mladih iskalcev zaposlitve je povzročilo veliko število brezposelnih.

3. Med industrijo in prebivalci mesta ter dnevnimi migranti obstaja dvosmerna povezava. Na eni strani predstavljajo prebivalci mesta in njegovega gravitacijskega zaledja potencialno industrijsko delovno silo, na drugi strani pa so porabniki industrijskih izdelkov. Z naraščanjem števila brezposelnih, padanjem realne vrednosti dohodkov v družini, staranjem prebivalstva in s tem povezanim spreminjanjem potrošniških navad, visokimi stroški bivanja in s padcem življenjskega standarda se zmanjšuje tudi poraba in upada povpraševanje po izdelkih. To pa industrijska podjetja, ki proizvajajo za mestno tržišče, sili v zmanjšanje industrijske proizvodnje.

4. Posledice deindustrializacije se $\mathrm{v}$ bolj ali manj izraziti obliki kažejo tudi v prostoru. Glede na to, da je deindustrializacija $v$ Mariboru sorazmerno mlad proces, še ni tako negativnih posledic v prostoru, kakršne poznamo iz kapitalističnih držav. Do leta 1992 so v mestu zaprli samo Tovarno čevljev Lilet v Melju. Podjetje Trend iz Grosuplja je sicer sprva skušalo obnoviti proizvodnjo čevljev, vendar je zaradi različnih pravnih zapletov tovarna kmalu prenehala obratovati. Tovarniške dvorane $\mathrm{v}$ osrednjem delu industrijske cone Melje danes zaseda blagovnica. Glede na število prijavljenih stečajev v letu 1992 lahko pričakujemo, da se bodo s podobnimi problemi srečevala 
tudi druga podjetja. To bi lahko pripeljalo do nastanka propadajočih industrijskih predelov v mestu, zmanjšanje obsega industrijskih površin in do bistvenih sprememb v funkcijski rabi mestnega prostora.

Deindustrializacija že sedaj zelo negativno vpliva na populacijski in s tem tudi na prostorski razvoj mesta oziroma na njegovo širitev. V prihodnje pa se lahko te razmere še zaostrijo. Z upadom življenjskega standarda, odpuščanjem delavcev, naraščanjem števila brezposelnih in nerešenimi stanovanjskimi problemi mladih družin, se bo $\mathbf{v}$ prihodnje še manj mladih odločalo za rojstvo otroka. Nizka rodnost in naraščajoča smrtnost bosta $\mathrm{v}$ povezavi s šibkim doseljevanjem prebivalcev $\mathrm{v}$ mesto zavrla populacijski in s tem tudi prostorski razvoj mesta.

Vedno večje bodo tudi socialne razlike med posameznimi mestnimi predeli. $\mathrm{Za}$ Maribor, znan po visoki zgostitvi v industriji zaposlenih delavcev, je bila že od nekdaj značilna socialna diferenciacija mestnega prostora. Glede na to, da je prvi val deindustrializacije zajel $v$ glavnem nekvalificirane in polkvalificirane delavce oziroma tiste $\mathrm{z}$ nižjo stopnjo izobrazbe, lahko pričakujemo, da se bodo v prihodnje še poglobile socialno-ekonomske razlike med posameznimi mestnimi predeli. Nenazadnje ne smemo pozabiti, da se deindustrializacija s svojimi učinki ne ustavi na mestnih mejah. Deindustrializacija bo, zaradi velikega števila predvsem nižje kvalificiranih delavcev, ki dnevno prihajajo na delo v Maribor, zajela celotno gravitacijsko območje mesta. V preteklosti je zaposlovanje $\mathrm{v}$ mariborski industriji intenzivno preobrazilo kmečka gospodinjstva v polkmečka in nekmečka. Na podeželju se je močno povečalo število prebivalcev, ki niso bili več eksistenčno odvisni od kmetijstva. V novih razmerah, $v$ katerih so številni dnevni migranti postali presežni delavci, se bo verjetno pojavil obratni proces: ponovno vračanje $\mathrm{k}$ zemlji in preživljanje $\mathrm{s}$ kmetijstvom, predvsem intenzivnim vinogradništvom, sadjarstvom, vrtnarstvom in poljedelstvom. Številni presežni delavci se bodo odločili tudi za kmečki turizem in odpiranje trgovin za lokalno prebivalstvo. Te tendence so že opazne $v$ neposrednem mestnem zaledju. Glede na to, da so si delavsko-kmečka in nekmečka gospodinjstva s podeželja že $v$ preteklosti svoj življenjski standard zviševala $\mathrm{z}$ delom na zemlji, zaradi deindustrializacije ne bodo tako ogrožena kot mestna gospodinjstva.

Položaj mariborske industrije leta 1992 smo ugotavljali z anketo. Nanjo je odgovorilo 32 podjetij. Na Temeljnem sodišču v Mariboru smo dobili podatek, da je bilo do konca meseca maja 1992 na sodišču sproženih šest stečajnih postopkov v industrijskih podjetjih. V Marlesu in Cevovodu se je stečajni postopek končal s prisilno poravnavo dolgov upnikom. Tudi $v$ Tovarni perila in konfekcije je bila uvedena prisilna poravnava. Stečajni postopek Tovarne obutve Lilet, ki se je začel leta 1989, še ni bil zaključen. Aprila in maja 1992 pa so bili sproženi še stečajni postopki v Gumarni, Tovarni industrijske pralne in procesne opreme in Tovarni stikalnih naprav. 
Na vprašanje, če je podjetje $v$ gospodarskih težavah, je kar 26 podjetij ali $81,24 \%$ vseh anketiranih tovarn in obratov odgovorilo pritrdilno. Negativne odgovore smo dobili v Tovarni kovinske opreme Primat (predelava kovin), družbenem podjetju Mlin-testenine in Tovarni mesnih izdelkov, Mešalnici močnih krmil in silosi in OEMV Mapetrol (predelava naftnih derivatov). V Henklu-Zlatorogu se s težavami srečujejo občasno.

Med 32 anketiranci jih šest ni želelo odgovoriti na vprašanje kolikokrat so imela podjetja leta 1991 blokiran žiro račun. $V$ desetih podjetjih so izjavili, da blokade ni bilo. $V$ dveh podjetjih so imeli žiro račun blokiran celo leto, $v$ enem podjetju pol leta, $\mathrm{v}$ preostalih trinajstih pa so se vrednosti gibale med 1 in 18-krat (v povprečju 7-krat v teh 13 podjetjih).

Podjetja smo $v$ anketi povprašali tudi za mnenje o vzrokih za slab gospodarski položaj njihovega podjetja. Na voljo so imeli trinajst odgovorov; med njimi so lahko izbrali tri, ki so bili najpomembnejši za stagnacijo in nazadovanje njihovega podjetja. Ovrednotili so jih s točkami od 3 do 1 . Pri tem so $\mathrm{z}$ vrednostjo tri označili razlog, ki je bil najpomembnejši, $z$ vrednostjo ena pa razlog, ki je bil najmanj pomemben.

Upoštevali smo odgovore 27 podjetij, ki so se znašla v gospodarskih težavah. Vsa podjetja skupaj so zbrala 146 točk. Po številu doseženih točk si vzroki sledijo v tem zaporedju:

1. Izguba tržišča v nekdanji Jugoslaviji ( 52 točk ali $35,6 \%$ ).

2. Zastarelost proizvodnih sredstev (19 točk ali $13,0 \%$ ).

3. Težave ob prehodu na tržno gospodarstvo (13 točk ali $8,9 \%$ ).

4. Nekonkurenčnost na tujem tržišču (12 točk ali $8,2 \%$ ).

5. Zgrešena razvojna politika podjetja v preteklem obdobju ( 6 točk ali $4,1 \%$ ).

6. Nezmožnost prestrukturiranja proizvodnje ( 5 točk ali $3,4 \%$ ).

7. Izguba tržišča v tujini ( 4 točke ali $2,7 \%$ ).

8. Slaba oskrba s surovinami, materialom, polizdelki... iz nekdanje Jugoslavije ( 3 točke ali $2,1 \%$ ).

9. Slaba organiziranost proizvodnega procesa (1 točka ali $0,7 \%$ ).

Nobeno izmed anketiranih podjetij ni navedlo kot razlog za slab gospodarski položaj slabo kakovost izdelkov, slabo oskrbo s surovinami in polizdelki iz tujine in lokacijske probleme (pomanjkanje prostora za širitev podjetja, slaba komunalna opremljenost zemljišča itd.). 


\section{LITERATURA}

Fothergill, S.; Guy, N. 1990: Retreat from the Regions. London.

Martin, R.; Rowthorn, B. 1986: The Geography of De-Industrialization. Hong Kong.

Mesečna informacija Republiškega zavoda za zaposlovanje, Območna enota Maribor, marec 1992. Maribor.

Slavec, A. 1991: Razvoj industrije v Maribor s posebnim poudarkom na razvojnih dejavnikih. Dela št. 8, str. 53-56. Ljubljana.

Slavec, A. 1992: Industrija Maribora. Magistersko delo. Ljubljana.

Slavec, A. 1992: Industrial Change in Maribor. Slowenien auf dem Weg in die Marktwirtschaft. Arbeitsmaterialen zur Raumordnung und Raumplanung, št. 108, str. 68-87. Bayreuth.

Pak, M.; Slavec, A. 1994: Gospodarska problematika Maribora. Maribor - Marburg: prispevki h geografiji prijateljskih mest v Sloveniji in Nemčiji, str. 84-100. Maribor.

Pak, M.; Slavec, A. 1994: Wirtschaftsstruktur und Entwicklung. Marburg - Maribor: geographische Beitraege ueber die Partnerstaedte in Deutschland und Slowenien. Marburger geographische Schriften, št. 126, str. 230-247. Marburg-Lahn.

The Dictionary of Human Geography, 1990. Second Edition. Oxford. str. 97.

Vrišer, I. 1977: Industrializacija Slovenije. Ljubljana.

Zakon o delovnih razmerjih in Zakon o zaposlovanju in zavarovanju, februar 1991. UL Republike Slovenije. Ljubljana.

\section{CHARACTERISTICS, CAUSES AND RESULTS OF DEINDUSTRIALIZATION IN MARIBOR}

\section{Summary}

Towards the end of the 80 's of this century, Maribor, one of the oldest industrial centers in Slovenia and by 1960 also the biggest one, passed through one of the most dramatic periods in the history of its economy. Namely, the co-called 'negative deindustrialization' occurred when the industrial share of social product began to decline, which, consequently, had negative impact on the growth of the entire economy of this city. Parallel to this, the number of workers who lost their jobs commenced to increase, and these could not get employed in service activities. As a result, the number of the unemployed drastically increased.

According to analyses, 28,397 workers were employed in the manufacturing industry of Maribor in 1991, which means only 724 workers more than in 1961. By 1993, the number further declined and dropped to 25,214 workers. The sudden turnover in the 
employment policy occurred after the year 1987 ; in this year, manufacturing industry reached the peak with 38,510 workers employed. After this culminating year, every fourth worker lost job in manufacturing industry. If compared to the rest of Slovenia, the decline in Maribor was much more radical. Besides, the share of industry in social product began to reduce. While in 1988 manufacturing industry in the Maribor municipality contributed $55.24 \%$ of social product, its share reduced to $43.47 \%$ by 1990 . Thus, after 1987, the economic significance of manufacturing industry also began to decline, so within the scope of economy of the city as within the scope of entire Slovenian manufacturing industry.

The reasons that drove the manufacturing industry of Maribor into such a situation were several and mutually intertwined. One of the basic reasons was the decentralization of industrial production in Slovenia after World War II which resulted from the industrialization policy and the policy of polycentric development. Then follow the changes in the evaluation of individual location factors, the old industrial plants or outmoded production means (modest investments into manufacturing industry), specific branch structure of this industry in Maribor, non-rational employment policy in the past based on non-economic fundaments (concealed unemployment), and, last but not least, difficulties in the transition to market oriented economy.

The result of the de-industrialization process are evident in the intense decline in the number of the employed in manufacturing industry and the rapid increase in the number of the unemployed in Maribor; they were 9,981 in number in March 1992, which meant $10.54 \%$ of the total number of the unemployed in Slovenia. The high degree of unemployment in that year was, to a great extent, an indirect result of de-industrialization, since those workers who had lost their job in industry, represented but a minor share of the unemployed population. The fact is that after 1987, the employing of new workers in manufacturing industry ceased. The effects of de-industrialization are also felt in the fast lowering of the standard of living of the people in Maribor, which consequently forced the industrial enterprises in Maribor producing for the city market, to further reduce the industrial production. The results are felt, more or less explicitly, also in space. In Maribor where de-industrialization is a relatively recent process, such negative effects in space as known in the industrially highly developed countries have not been felt so much yet. In the future, disintegrating industrial quarters of the city may occur, the extent of industrial areas may be reduced, and the functional use of the city space may be changed essentially. However, negative effects are already felt today: low natural increase and poor immigration of population; together with the increasing mortality, it all already influences the stagnation of population and, consequently, also of spatial development. 